\title{
PENGARUH FAKTOR-FAKTOR PROFESIONALISME AUDITOR dan ETIKA PROFESI TERHADAP TINGKAT MATERIALITAS DALAM PEMERIKSAAN LAPORAN KEUANGAN
}

\begin{abstract}
Audit of financial statements is the most recognized services than other services, also referred to as traditional services. This service is a service that is often used by parties outside the company to assess the company and make decisions relating to the company. In this case the financial statement is the basis for decision making. Financial Lapoaran influenced by the materiality level, because materiality helps the auditor to gather sufficient evidence for the reliability of a financial statement. The title of this research Influence Factors Auditor Professionalism and Professional Ethics On The Level Examination Materiality in Financial Reporting.

Type of research is descriptive. The population in this study is the auditor who worked on the Public Accounting Firm ( KAP) in the city of Semarang. Sampling was done by purposive sampling, and the type of primary data. Analysis techniques in this study using a test testing data quality, validity, and reliability testing. Covers the classical assumption normality test, multicollinearity and heteroscedasticity test and hypothesis testing, regression test, $t$-test, fand testing the coefficient of determination ( $R 2$ ).

Based on the analysis, t-test ( partial) variable social obligations significance value 0.084 and 0.086 significance value professional ethics do not have a significant effect on the level of materiality, while the variable devotion to the profession with a significance value of 0.017 , with a significance value of 0.007 independence, confidence in the profession with values 0.005 significance and relationship with peers significance value of 0.002 has a significant influence on the level of materiality and test results $F$ ( simultaneous) variable devotion to the profession, social responsibility, self-reliance, confidence in the profession, relationships with colleagues and professional ethics with a value of 0,000 collectively sigifikasi same effect on the level of materiality. Dedication to the profession, self-reliance, confidence in the profession, relationships peers, and professional ethics considerations affect the materiality level so as to produce quality financial statements.
\end{abstract}

Keywords : Devotion to the profession, Social obligations, Independence, Confidence profession, Relationships with colleagues, Professional ethics, Consideration of materiality levels

\section{PENDAHULUAN}

Audit adalah jasa profesi yang dilakukan oleh kantor Akuntan Publik dan dilaksanakan oleh seorang auditor yang sifatnya sebagai jasa pelayanan. Standar Profesi Akuntan Publik mengharuskan dibuatnya laporan disetiap kali melakukan audit. Suatu perusahaan memerlukan auditor untuk melakukan audit terhadap laporan keuangan, dimana perlunya seorang auditor eksternal yang memiliki pandangan profesionalisme yang tinggi akan memberikan kontribusi yang dapat dipercaya oleh pengambil keputusan.

Profesionalisme juga menjadi syarat utama bagi seseorang yang ingin menjadi seorang auditor eksternal. 
Professional berarti bertanggung jawab yang dibebankan kepadanya dan lebih dari sekedar memenuhi undang-undang dan peraturan masyarakat. Materialitas itu sendiri adalah nilai salah saji informasi akuntansi yang dapat mempengaruhi pihak-pihak pemakai informasi tersebut. Materialitas adalah dasar penetapan standar auditing tentang standar pekerjaan lapangan dan standar pelaporan. Materialitas memiliki pengaruh yang mencakup semua aspek audit dalam audit atas laporan keuangan. (Sri Trisnaningsih, 2010).

Pada kenyataannya di dalam melaksanakan tugasnya auditor harus memperhatikan kredibilitas dan etika profesi. Kode etik merupakan norma yang mengatur sikap, tingkah laku dan tata krama dari para anggotanya. Dalam melaksanakan profesinya, seorang auditor harus mematuhi kode etik akuntan yang mengatur hubungan antara auditor dan dengan kliennya maupun antara profesi dengan masyarakat. Seorang auditor profesional harus mentaati peraturan kode etik dalam setiap perilakunya, karena hal tersebut berpengaruh pada kualitas jasa yang mereka berikan. Etika profesi merupakan pedoman bagi para auditor dalam melakukan tugasnya, maka dituntut adanya pemahaman yang baik mengenai kode etika profesi dalam memberikan jasa akuntansi.

Hasil penelitian Iriyadi dan Vannywati (2011) menunjukkan bahwa etika profesi berpengaruh positif terhadap tingkat materialitas, namun penelitian Desiana (2012) menunjukkan bahwa etika profesi berpengaruh negatif terhadap pertimbangan tingkat materialitas. Oleh karena itu karena adanya kontradiksi hasil penelitian maka penelitian ini layak diteliti kembali. Penelitian ini merupakan replikasi penelitian yang dilakukan oleh Hendro Wahyudi (2006). Perbedaan penelitian ini dengan penelitian sebelumnya, adalah objek penelitiannya. Judul penelitian ini adalah : PENGARUH FAKTOR-FAKTOR PROFESIONALISME AUDITOR DAN ETIKA PROFESI TERHADAP TINGKAT MATERIALITAS DALAM PEMERIKSAAN LAPORAN KEUANGAN

\section{TELAAH LITERATUR DAN PENGEMBANGAN HIPOTESIS}

\section{Pengertian Profesionalisme}

Profesi dan profesionalisme dapat dibedakan secara konseptual. “Profesi merupakan jenis pekerjaan yang memenuhi beberapa kriteria, sedangkan profesionalisme merupakan suatu atribut individual yang penting tanpa melihat suatu pekerjaan merupakan suatu profesi atau tidak" (Kalbers dan Fogart, 1995 dalam Faisal et al., 2012). Seorang auditor bisa dikatakan profesional apabila telah memenuhi dan mematuhi standar-standar kode etik yang telah ditetapkan oleh IAI.

Profesionalisme yang digunakan adalah konsep untuk mengukur bagaimana para profesional memandang profesi mereka yang tercermin dalam sikap dan perilaku mereka. Dengan anggapan bahwa sikap dan perilaku mempunyai hubungan timbal balik. Perilaku profesionalisme merupakan cerminan dari sikap profesionalisme, demikian pula sebaliknya sikap profesional tercermin dari perilaku yang profesional. Sikap profesional tercermin pada pelaksanaan kualitas yang merupakan karakteristik atau tanda suatu profesi atau seorang profesional. Dalam pengertian umum, seseorang dikatakan profesional jika memenuhi tiga kriteria, yaitu mempunyai keahlian untuk melaksanakan tugas sesuai dengan bidangnya, melaksanakan suatu tugas atau profesi dengan menetapkan standar baku di bidang profesi yang bersangkutan, dan menjalankan tugas profesinya dengan mematuhi etika profesi yang ditetapkan.

Menurut Hall R dalam syahrir (2004) terdapat lima dimensi profesionalisme, yaitu: 


\section{Pengabdian Pada Profesi}

Pengabdian pada profesi dicerminkan dari dedikasi profesionalisme dengan menggunakan pengetahuan dan kecakapan yang dimiliki. Keteguhan untuk tetap melaksanakan pekerjaan meskipun imbalan ekstrinsik kurang. Sikap ini adalah ekspresi dari pencurahan diri yang total terhadap pekerjaan. Pekerjaan didefinisikan sebagai tujuan, bukan hanya sebagai alat untuk mencapai tujuan. Totalitas ini sudah menjadi komitmen pribadi, jadi bukan semata mata karena materi tapi kompensasi utama yang diharapkan dari pekerjaan adalah kepuasan rohani, baru kemudian materi.

\section{Kewajiban Sosial}

Kewajiban sosial adalah pandangan tentang pentingnya peranan profesi dan manfaat yang diperoleh baik masyarakat maupun profesional karena adanya pekerjaan tersebut.

\section{Kemandirian}

Kemandirian dimaksudkan sebagai suatu pandangan seseorang yang profesional harus mampu membuat keputusan sendiri tanpa tekanan atau pengaruh dari pihak lain (pemerintah, klien, dan bukan anggota profesi). Setiap ada campur tangan dari luar dianggap sebagai hambatan kemandirian secara profesional.

\section{Keyakinan Profesi}

Keyakinan terhadap peraturan profesi keyakinan terhadap profesi adalah suatu keyakinan bahwa yang paling berwenang menilai pekerjaan profesional adalah rekan sesama profesi, buakan orang luar yang tidak mempunyai kompetensi dalam bidang ilmu dan pekerjaan mereka.

\section{Hubungan Dengan Rekan Seprofesi}

Hubungan dengan sesama profesi adalah menggunakan ikatan profesi sebagai acuan, termasuk didalamnya organisasi formal dan kelompok kolega informal sebagai ide utama dalam pekerjaan. Melalui ikatan profesi ini para profesional membangun kesadaran profesional.

\section{Pengertian Etika Profesi}

Etika secara umum didefiniskan sebagai nilai-nilai tingkah laku atau aturan-aturan tingkah laku yang diterima dan digunakan oleh suatu golongan tertentu atau individu. Etika profesi merupakan karakteristik suatu profesi yang membedakan suatu profesi dengan profesi lain, yang berfungsi untuk mengatur tingkah laku para anggotanya (Murtanto dan Marini, 2003 dalam Desiana 2012).

\section{Pengertian Materialitas}

Tujuan penetapan materialitas ini adalah untuk membantu auditor merencanakan pengumpulan bahan bukti yang cukup. Menurut Boynton et al (2006:2) dalam Desiana (2012) menyatakan bahwa "materiality is one of the factors that affects the auditor's judgment about the sufficiency (quantity needed) of evidential matter". Hal ini berarti semakin rendah tingkat materialitas,semakin besar jumlah bukti yang diperlukan. Sehingga dapat dikatakan bahwa diperlukan lebih banyak bukti untuk memperoleh keyakinan yang memadai mengenai salah saji material. Peran konsep materialitas itu adalah untuk mempengaruhi kualitas dan kuantitas informasi akuntansi yang diperlukan oleh auditor dalam membuat keputusan yang berkaitan dengan bukti. Konsep materialitas menyatakan bahwa tidak semua informasi keuangan diperlukan atau tidak semua informasi seharusnya dikomunikasikan. Pertimbangan awal tingkat materialitas adalah jumlah maksimum salah saji 
dalam laporan keuangan yang menurut pendapat auditor, tidak mempengaruhi pengambilan keputusan dari pemakai. Penentuan jumlah nilai ini adalah salah satu keputusan terpenting yang diambil oleh auditor, yang memerlukan pertimbangan profesional yang memadai.

Tujuan penetapan materialitas ini adalah untuk membantu auditor merencanakan pengumpulan bahan bukti yang cukup. Jika auditor menetapkan jumlah yang rendah maka lebih banyak bahan bukti yang harus dikumpulkan dari pada jumlah yang tinggi. Begitu juga sebaliknya. Seringkali mengubah jumlah materialitas dalam pertimbangan awal ini selama audit. Jika ini dilakukan, jumlah yang baru tadi disebut pertimbangan yang direvisi mengenai materialitas. Sebab-sebabnya antara lain perubahan faktor-faktor yang digunakan untuk menetapkannya, atau auditor berpendapat jumlah dalam penetapan awal tersebut terlalu kecil atau besar.

\section{Hipotesis Penelitian}

\section{Pengaruh Pengabdian Pada Profesi Terhadap Pertimbanagn Tingkat Materialitas}

Pengabdian pada profesi dicerminkan dari dedikasi profesionalisme dengan menggunakan pengetahuan dan kecakapan yang dimiliki. Pekerjan didefinisikan sebagai tujuan, bukan hanya sebagai alat untuk mencapai tujuan. Totalitas ini sudah menjadi komitmen pribadi, sehingga kompensasi utama yang diharapkan dari pekerjaan adalah kepuasan rohani, baru kemudian materi. Dengan totalitas yang dimiliki auditor akan lebih berhati-hati dan bijaksana melakukan audit, sehingga menghasilkan output yang berkualitas. Berdasarkan uraian diatas maka hipotesis yang dapat dirumuskan adalah sebagai berikut:

H1 : Ada pengaruh pengabdian pada profesi terhadap pertimbangan tingkat materialitas.

\section{Pengaruh Kewajiban Sosial Terhadap Pertimbangan Tingkat Materialitas}

Penelitian sebelumnya yang dilakukan oleh Hastuti et al (2003) dalam Desiana (2012) menyatakan bahwa kewajiban sosial mempunyai hubungan yang positif terhadap tingkat materialitas. Kewajiban sosial adalah suatu pandangan tentang pentingnya peranan profesi serta manfaat yang diperoleh baik masyarakat maupun profesional karena adanya pekerjaan tersebut (Wahyudi dan Aida, 2006 dalam Desiana, 2012). Kesadaran auditor tentang peran profesinya di masyarakat akan menumbuhkan sikap mental untuk melakukan pekerjaan sebaik mungkin. Maka hipotesisnya :

\section{H2 : Ada pengaruh kewajiban sosial terhadap pertimbangan tingkat materialitas}

\section{Pengaruh Kemandirian Terhadap Pertimbangan Tingkat Materialitas}

Kemandirian dimaksudkan sebagai suatu pandangan seseorang yang profesional harus mampu membuat keputusan sendiri tanpa tekanan dari pihak lain (pemerintah, klien, mereka yang bukan anggota profesi). Pertimbangan-pertimbangan yang dibuat harus benar-benar berdasarkan pada kondisi dan keadaan yang dihadapi dalam proses pengauditan. Semakin tinggi kemandirian diharapkan akan menghasilkan pertimbangan tingkat materialitas dengan lebih baik. Hipotesis yang diajukan:

\section{H3 : Ada pengaruh kemandirian terhadap pertimbangan tingkat materialitas.}




\section{Pengaruh Keyakinan Profesi Terhadap Tingkat Pertimbangan Materialitas}

Keyakinan terhadap profesi adalah suatu keyakinan bahwa yang paling berwenang menilai pekerjaan profesional adalah rekan sesama profesi, bukan orang luar yang tidak mempunyai kompetensi dalam bidang ilmu dan pekerjaan auditor. Bila yang menilai pekerjaan mempunyai pengetahuan yang sama, maka kesalahan akan dapat diketahui. Semakin tinggi keyakinan pada profesi diharapkan akan menghasilkan pertimbangan tingkat materialitas yang lebih baik (Marfin \& Jaka, 2012). Hipotesis yang ditunjukkan dari uraian tersebut :

H4 : Ada pengaruh keyakinan profesi terhadap pertimbangan tingkat materialitas

\section{Pengaruh Hubungan Dengan Rekan Seprofesi Terhadap Tingkat Materialitas}

Hubungan dengan sesama profesi adalah menggunakan ikatan profesi sebagai acuan, termasuk didalamnya organisasi formal dan kelompok kolega informal sebagai ide utama dalam pekerjaan. Melalui ikatan profesi ini para profesionalisme membangun kesadaran profesional. Dengan banyaknya tambahan masukan akan menambah akumulasi pengetahuan auditor sehingga dapat lebih bijaksana dlam membuat perencanaan dan pertimbangan dalam proses pengauditan (Wiedhani, 2006 dalam Marfin \& Jaka, 2012). Berdasarkan uraian diatas maka hipotesis yang dapat dirumuskan adalah sebagai berikut:

\section{H5 : Ada pengaruh hubungan dengan rekan seprofesi terhadap pertimbangan tingkat materialitas}

\section{Pengaruh Etika Profesi Terhadap Tingkat Materialitas}

Etika profesi merupakan karakteristik suatu profesi yang membedakan suatu profesi dengan profesi lain, yang berfungsi untuk mengatur tingkah laku para anggotanya (Murtanto dan Marini, 2003 dalam Desiana 2012). Seorang yang profesional mempunyai tanggung jawab yang lebih besar karena diasumsikan bahwa seorang profesional memiliki kepintaran, pengetahuan, dan pengalaman untuk memahami dampak aktifitas yang dilakukan (Iriyadi dan Vannywati, 2011). Agar dapat dipercaya oleh masyarakat maka diperlukan landasan etika dan moral, oleh karena itu, akuntan harus mengacu pada kode etik akuntan untuk dapat mempertahankan independensi, objektifitas, dan profesionalismenya dalam melaksanakan tugasnya. Penelitian yang dilakuan oleh Iriyadi dan Vannywati (2011) mengemukakan bahwa etika profesi berpengaruh positif terhadap pertimbangan tingkat materialitas. Berdasarkan uraian diatas dapat dirumuskan hipotesis penelitian sebagai berikut:

\section{H6 : Ada pengaruh etika profesi terhadap pertimbangan tingkat materialitas}

\section{METODE PENELITIAN}

\section{Populasi dan Prosedur Penentuan Sampel}

Populasi dalam penelitian ini adalah auditor di kantor akuntan publik di Semarang. Sampel adalah sebagian atau wakil populasi yang diteliti (Sugiyono,2007:109). Prosedur Pengambilan sampel menggunakan teknik purposive sampling yaitu cara pengambilan sampel dari anggota populasi secara kriteria tertentu. 
Dengan kriteria yaitu auditor senior karena auditor senior lebih berpengalaman.

\section{Jenis dan Sumber Data}

Jenis data yang digunakan adalah data primer yang diperoleh melalui pengujian kuesioner kepada responden. Data primer secara khusus dikumpulkan melalui kuesioner yang berisi pertanyaan-pertanyaan yang berhubungan dengan penelitian, kemudian hasil dari ini diolah menjadi data yang menjelaskan hasil penelitian ini.

\section{Metode Pengumpulan Data}

Metode pengumpulan data adalah dengan menggunakan kuesioner yang sebagian dilakukan secara langsung oleh peneliti, masing-masing untuk membagikan kuesioner dan memberikan perintah untuk mengisi sesuai dengan kondisi yang ada dan sesuai dengan setiap item pertanyaan.

\section{Definisi Operasional dan Pengukuran Variabel Variabel Independen}

1. Profesionalisme, variabel ini diukur dengan menggunakan indikator yang mengacu pada instrumen penelitian Wahyudi dan Aida (2006:11) dalam Desiana (2012) dengan beberapa penyesuaian, yaitu penggunaan akuntan publik diganti dengan auditor. Indikator tersebut adalah sebagai berikut:
a) Pengabdian pada profesi
b) Kewajiban sosial
c) Kemandirian
d) Keyakinan profesi
e) Hubungan dengan rekan seprofesi

2. Etika profesi,Variabel ini diukur dengan indikator yang mengacu pada pendapat Murtanto dan Marini (2003:10) dalam Desiana (2012) dengan beberapa penyesuaian, yaitu penggunaan akuntan publik diganti dengan auditor. Indikator tersebut adalah sebagai berikut:
a) Kepribadian
b) Kecakapan profesional
c) Tanggung jawab
d) Pelaksanaan kode etik
e) Penafsiran dan penyempurnaan kode etik

\section{Variabel Dependen}

Pertimbangan tingkat materialitas, Variabel ini diukur dengan indikator yang mengacu pada pendapat Rifqi (2008:13) dalam Desiana (2012) dengan beberapa penyesuaian, yaitu penggunaan akuntan publik diganti dengan auditor. Indikator tersebutr adalah sebagai berikut:

a) Seberapa penting tingkat materialitas

b) Pengetahuan tentang tingkat materialitas 
c) Resiko audit

d) Tingkat materialitas antar perusahaan

e) Urutan tingkat materialitas dalam rencana audit

\section{Teknik Analisis Data}

\section{Analisis Deskriptif}

Statistik deskriptif didefinisikan merupakan suatu metode dalam mengorganisir dan menganalisis data kuantitatif, sehingga diperoleh gambaran yang teratur mengenai suatu kegiatan. Ukuran yang digunakan dalam deskripsi antara lain: frekuensi, tendensi sentral (mean, median dan modus), dispersi (standar deviasi dan varian) dan koefisien korelasi antara variabel penelitian. Ukuran yang digunakan dalam statistik deskriptif tergantung pada tipe skala pengukuran construct yang digunakan dalam penelitian (Ghozali, 2006).

\section{Uji Kualitas Data}

\section{Uji Validitas}

Uji Validitas digunakan untuk mengukur sah atau valid tidaknya suatu kuesioner. Untuk mengetahui valid atau tidaknya suatu kuesioner, maka dilihat dari membandingkan nilai $r_{\text {hitung }}$ dengan $r_{\text {tabel }}$ yang diperoleh. Suatu kuesioner dikatakan valid jika nilai $r_{\text {hitung }}>r_{\text {tabel }}$ (Ghozali, 2006).

\section{Uji Reliabilitas}

Uji Reliabilitas adalah alat untuk mengukur suatu kuisioner yang merupakan indikator variabel atau konstruk. Suatu konstruk atau variabel dikatakan reliabel, jika memberi nilai Cronbach Alpha > 0,60 (Nunnally, 1960 dalam Ghozali, 2006).

\section{Uji Asumsi Klasik}

\section{Uji Normalitas}

Uji normalitas bertujuan untuk menguji apakah dalam metode regresi, variabel dependen dan variabel independen keduanya mempunyai distribusi normal atau tidak (Ghozali, 2006). Model regresi yang baik adalah yang memiliki distribusi normal atau mendekati normal. Pengujian distribusi normal dilakukan dengan cara melihat histogram yang membandingkan data observasi dengan distribusi yang mendekati normal. Disamping itu digunakan normal probability plot yang membandingkan distribusi kumulatif dari data yang sesungguhnya dengan distribusi kumulatif dari data distribusi normal. Jika distribusi normal, maka garis yang menggambarkan data sesungguhnya akan mengikuti garis diagonalnya

\section{Uji Multikolinieritas}

Uji multikolinearitas dimaksudkan untuk mendeteksi gejala korelasi antara variabel independen yang satu dengan variabel independen yang lain. Pada model regeresi yang baik seharusnya tidak terdapat korelasi antara variabel independen. Uji Multikolinieritas dapat dilakukan dengan 2 cara yaitu dengan melihat VIF (Variance Inflation Factors) dan nilai tolerance. Jika VIF $>10$ dan nilai tolerance $<0,10$ maka terjadi gejala Multikolinieritas (Ghozali, 2006). 


\section{Uji Heteroskedastisitas}

Uji heteroskedastisitas merupakan sebuah pengujian yang bertujuan untuk menguji apakah dalam satu model regresi terjadi ketidaksamaan varians dan residual satu pengamatan ke pengamatan yang lain jika berbeda maka disebut heteroskedastisitas (Ghozali, 2006). Ketidaksamaan varians dari error yang heterogen berarti terdapat masalah heteroskedastisitas dimana asumsi klasik mensyaratkan bahwa varians dari error harus bersifat homogen. Deteksi ada tidaknya heteroskedastisitas dengan melihat grafik scatterplot. Jika ada pola tertentu, seperti titik-titik yang membentuk pola tertentu, maka mengidentifikasi telah terjadi heteroskedastisitas. Jika tidak ada pola yang jelas, serta titik-titik menyebar di atas dan di bawah angka 0 pada sumbu Y, maka tidak terjadi heteroskedastisitas.

\section{Uji Hipotesis}

\section{Regresi Linier Berganda}

Pengujian hipotesis pada penelitian ini menggunakan metode regresi berganda. Analisis regresi berganda dimana dalam persamaan regresinya mengandung unsur interaksi (Ghozali, 2006). Model persamaan regresi berganda yang digunakan dalam penelitian ini adalah sebagai berikut :

$$
Y=a+b_{1} X_{1}+b_{2} X_{2}+b_{3} X_{3}+b_{4} X_{4}+b_{5} X_{5}+b_{6} X_{6}+e
$$

Keterangan :

$\mathrm{Y} \quad=$ Pertimbangan Tingkat Materialitas

$\mathrm{X}_{1} \quad=$ Pengabdian Pada Profesi

$X_{2}=$ Kewajiban Sosial

$\mathrm{X}_{3}=$ kemandirian

$\mathrm{X}_{4} \quad=$ Kepercayaan pada profesi

$X_{5}=$ Hubungan sesame rekan seprofesi

$\mathrm{X}_{6}=$ Etika profesi

a $=$ Konstanta

$b_{1} b_{2} b_{3}=$ Koefisien Regresi

\section{Uji t (Uji Parsial)}

Menurut Ghozali (2006) uji stastistik t pada dasarnya menunjukkan seberapa jauh pengaruh satu variabel independen secara individual dalam menerangkan variabel dependen. Jika tingkat probabilitasnya lebih kecil dari 0,05 maka dapat dikatakan variabel independen berpengaruh terhadap variabel dependen.

\section{Uji F (Uji Simultan)}

Menurut Ghozali (2006) uji stastistik F pada dasarnya menunjukkan apakah semua variabel independen atau variabel bebas yang dimaksudkan dalam model mempunyai pengaruh secara bersama-sama terhadap variabel dependen. Apabila tingkat probabilitasnya lebih kecil dari 0,05 maka dapat dikatakan bahwa semua variabel independen secara bersama-sama berpengaruh terhadap variabel terikat.

\section{Koefisien Determinasi}


Koefisien Determinasi $\left(\mathbf{R}^{2}\right)$ dipergunakan untuk mengetahui sampai seberapa besar prosentase variasi variabel bebas pada model dapat diterangkan oleh variabel terikat. Koefisien determinasi $\left(\mathbf{R}^{2}\right)$ dinyatakan dalam prosentase. Nilai $\mathbf{R}^{2}$ ini berkisar antara $0<\mathbf{R}^{\mathbf{2}}<100 \%$. Nilai Adjusted $\mathbf{R}^{2}$ dijelaskan oleh variabel penelitian dan sisanya dijelaskan oleh variabel lainnya. (Imam Ghozali , 2006 : 156)

\section{HASIL \& PEMBAHASAN}

\section{Gambaran Umum Responden}

Dalam penelitian ini, data penelitian dikumpulkan dengan mengirimkan 50 kuesioner (5 KAP x 10 kuesioner). 5 KAP etrsebut adalah KAP Ngurah Arya \& Rekan, KAP sugeng Pamudji, KAP Ruchendi, Mardjito \& Rushandi, KAP Riza, Adi, Syaril \& Rekan, dan KAP Drs. Rahardja, MSI, CPA. Kuesioner yang kembali berjumlah 48 kuesioner, sedangkan kuesioner yang dapat diolah berjumlah 46 kuesioner, hal ini dikarenakan ada 2 kuesioner yang tidak diisi secara lengkap.

Gambaran umum responden dalam penelitian ini dibagi berdasarkan jenis kelamin, usia, pendidikan, dan lama bekerja adalah sebagai berikut : sisipkan Tabel 1 pada lampiran.

\section{Uji Kualitas Data}

\section{Uji Validitas}

Untuk mengetahui valid atau tidaknya kuesioner akan dibandingkan antara nilai $r_{\text {tabel }}$ dengan nilai $r_{\text {hitung }}$ yang diperoleh. Nilai $r_{\text {tabel }}$ pada df $(n-2)=46-2=44$ adalah 0,297. Berdasarkan hasil pengujian validitas pada masing-masing indikator variabel menunjukkan nilai $r_{\text {hitung }}>$ nilai $_{\text {tabel }^{\prime}}$ oleh karena itu semua indikator variabel dapat dikatakan valid. Dapat dilihat pada tabel berikut : sisipkan Tabel 2 pada lampiran.

\section{Uji Reliabilitas}

Pengambilan keputusan untuk uji reliabilitas adalah bila niali alpha $>0,60$ maka instrumen dikatakan reliabel. Uji reliabilitas pada penelitian ini menunjukkan bahwa nilai alpha instrumen untuk semua variabel penelitian mempunyai nilai alpha $>0,60$, sehingga dapat dikatakn bahwa instrumen dalam penelitian ini adalah reliabel. Dapat dilihat pada tabel berikut : sisipkan Tabel 3 pada lampiran.

\section{Uji Asumsi Klasik}

\section{Uji Normalitas}

Uji normalitas bertujuan untuk menguji apakah dalam metode regresi, variabel pengganggu atau residual memiliki distrbusi normal. Cara untuk medeteksi apakah residual berdistribusi normal atau tidak yaitu dengan analisis. Analisa grafik dilakukan dengan melihat grafik normal P-P plot dari model regresi. Model regresi dikatakan normal bila data menyebar disekitar garis diagonal dan mengikuti arah garis diagonalnya (Ghozali, 2006). Hasil normalitas adalah sebagai berikut : sisipkan Tabel 4 pada lampiran. Berdasarkan grafik di atas, terlihat bahwa titik-titik menyebar di sekitar garis diagonal dan mengikuti arah diagonal yang membentuk sudut $45^{\circ}$, maka diambil kesimbulan bahwa model regresi memenuhi asumsi normalitas.

\section{Uji Multikolinearitas}


Pengujian multikolinearitas bertujuan untuk menguji apakah model regresi ditemukan adanya korelasi antar variabel bebas (independen). Model regresi yang baik seharusnya tidak terjadi korelasi diantara variabel independen. Untuk melihat ada atau tidaknya multikolinearitas maka dilakukan dengan melihat nilai Tolerance dan lawannya Variance Inflation Factor (VIF). Apabila nilai Tolerance $>0,1$ dan nilai VIF $<10$ maka tidak terjadi multikolinearitas antar variabel independennya (Ghozali, 2006). Hasil normalitas adalah sebagai berikut : sisipkan Tabel 5 pada lampiran. Berdasarkan tabel di atas, maka dapat diketahui bahwa nilai tolerance semua variabel $>0,1$ dan nilai VIF semua variabel $<10$. Sehingga dapat disimpulkan bahwa model regresi linier tidak terdapat korelasi antar variabel bebas.

\section{Uji Heteroskedatisitas}

Uji heteroskedastisitas dilakukan dengan menggunakan grafik scatter plot. Bila grafik membentuk pola tertentu, seperti titik yang ada membentuk pola tertentu yang teratur (bergelombang, melebar kemudian menyempit), maka mengindikasikan terjadi heterokedastisitas. Bila grfik terdapat titik - titik yang menyebar di atas dan di bawah angka nol pada sumbuY, maka tidak terjadi heterokedatisitas. Model regresi yang baik adalah tidak terjadi heteroskedastisitas. Hasil grafik scatterplot sebagai berikut : sisipkan Tabel 6 pada lampiran. Berdasarkan grafik di atas terlihat bahwa titik - titik menyebar secara acak di atas dan di bawah angka nol pada sumbu Y, dan tidak membentuk pola tertentu. Sehingga model regresi ini tidak terjadi heteroskedastisitas.

\section{Pengujian Hipotesis}

\section{Uji F (Uji Simultan)}

Menurut Ghozali (2006) uji stastistik F pada dasarnya menunjukkan apakah semua variabel independen atau variabel bebas yang dimaksudkan dalam model mempunyai pengaruh secara bersama-sama terhadap variabel dependen. Apabila tingkat probabilitasnya lebih kecil dari 0,05 maka dapat dikatakan bahwa semua variabel independen secara bersama-sama berpengaruh terhadap variabel terikat. Hasil pengujian ini dapat dilihat pada tabel berikut : sisipkan Tabel 7 pada lampiran. Berdasarkan tabel di atas diketahui bahwa nilai signifikansinya sebesar 0,000 atau < 0,05, dengan demikian persamaan semua variabel pengabdian pada profesi, kewajiban sosial, kemandirian, keyakinan pada profesi, hubungan rekan seprofesi, dan etika profesi secara bersama-sama berpengaruh terhadap pertimbangan tingkat materialitas akuntan publik. dengan demikian model regresi dalam penelitian ini adalah tergolong fit/layak guna penelitian.

\section{Uji t (Uji Parsial)}

Berdasarkan perhitungan uji regresi berganda yang tercantum pada table di bawah ini (sisipkan Tabel 8 pada lampiran). Maka hasilnya memberikan pengertian bahwa :

\section{Hipotesis 1 : Pengaruh pengabdian Pada Profesi Terhadap Pertimbangan Tingkat Materialitas}

Hasil perhitungan tabel 4.9, diperoleh nilai signifikasi untuk pengabdian pada profesi adalah $a=0,017$ $<0,05$ menandakan bahwa pengabdian pada profesi mempunyai pengaruh terhadap pertimbangan tingkat materialitas akuntan publik. Dengan demikian dapat disimpulkan bahwa $\mathrm{H} 1$ diterima.

\section{Hipotesis 2 :Pengaruh kewajiban sosial Terhadap Pertimbangan Tingkat Materialitas}

Hasil perhitungan tabel 4.9, diperoleh nilai signifikasi untuk kewajiban sosial adalah $a=0,084>0,05$ 
menandakan bahwa kewajiban mempunyai pengaruh tidak signifikan terhadap pertimbangan tingkat materialitas akuntan publik. Dengan demikian dapat disimpulkan bahwa H2 ditolak.

\section{Hipotesis 3 :Pengaruh kemandirian Terhadap Pertimbangan Tingkat Materialitas}

Hasil perhitungan tabel 4.9, diperoleh nilai signifikasi untuk kemandirian adalah $a=0,007<0,05$ menandakan bahwa kewajiban mempunyai pengaruh signifikan terhadap pertimbangan tingkat materialitas akuntan publik. Dengan demikian dapat disimpulkan bahwa H3 diterima.

\section{Hipotesis 4 :Pengaruh Keyakinan Pada Profesi Terhadap Pertimbangan Tingkat Materialitas}

Hasil perhitungan tabel 4.9, diperoleh nilai signifikasi untuk keyakinan pada profesi adalah $a=0,005<$ 0,05 menandakan bahwa keyakinan pada profesi mempunyai pengaruh signifikan terhadap pertimbangan tingkat materialitas akuntan publik. Dengan demikian dapat disimpulkan bahwa H4 diterima.

\section{Hipotesis 5 :Pengaruh Hubungan Rekan Seprofesi Terhadap Pertimbangan Tingkat Materialitas}

Hasil perhitungan tabel 4.9, diperoleh nilai signifikasi untuk hubungan rekan seprofesi adalah $a=0,002<$ 0,05 menandakan bahwa hubungan rekan seprofesi mempunyai pengaruh signifikan terhadap pertimbangan tingkat materialitas akuntan publik. Dengan demikian dapat disimpulkan bahwa H5 diterima.

\section{Hipotesis 6 :Pengaruh Etika Profesi Terhadap Pertimbangan Tingkat Materialitas}

Hasil perhitungan tabel 4.9, diperoleh nilai signifikasi untuk etika profesi adalah $a=0,086>0,05$ menandakan bahwa etika profesi mempunyai pengaruh tidak signifikan terhadap pertimbangan tingkat materialitas akuntan publik. Dengan demikian dapat disimpulkan bahwa H6 ditolak.

\section{Koefisien Determinasi $\left(\mathbf{R}^{2}\right)$}

Nilai koefisien determinasi untuk variabel pengabdian pada profesi, kewajiban sosial, kemandirian, keyakinan pada profesi, hubungan rekan seprofesi, dan etika profesi dapat menjelaskan pertimbangan tingkat materialitas akuntan publik sebesar 73,50 \% sedangkan sisanya diterangkan oleh faktor lain yang tidak diamati dalam penelitian ini, seperti kualitas audit, pengetahuan mendeteksi kekeliruan dan lain-lain. Sisipkan Tabel

\section{9 pada lampiran}

\section{SIMPULAN}

Berdasarkan hasil penelitian yang telah dilakukan, maka dapat dibuat kesimpulan sebagai berikut:

a. Pengabdian pada profesi berpengaruh signifikan terhadap pertimbangan tingkat materialitas akuntan publik, kondisi ini terjadi karena pengabdian pada profesi dicerminkan dari dedikasi profesionalisme dengan menggunakan pengetahuan dan kecakapan yang dimiliki. Pekerjan didefinisikan sebagai tujuan, bukan hanya sebagai alat untuk mencapai tujuan. Dengan totalitas yang dimiliki auditor akan lebih berhati-hati dan bijaksana melakukan audit, sehingga menghasilkan output yang berkualitas.

b. Kewajiban sosial berpengaruh tidak signifikan terhadap pertimbangan tingkat materialitas akuntan publik, kondisi ini terjadi karena sampel dalam penelitian ini sebagai besar adalah auditor Junior, sehingga kewajiban sosial belum begitu dirasakan.

c. Kemandirian berpengaruh signifikan terhadap pertimbangan tingkat materialitas akuntan publik, kondisi ini terjadi karena kemandirian dimaksudkan sebagai suatu pandangan seseorang yang profesional harus 
mampu membuat keputusan sendiri tanpa tekanan dari pihak lain (pemerintah, klien, mereka yang bukan anggota profesi)

d. Keyakinan pada profesi berpengaruh signifikan terhadap pertimbangan tingkat materialitas akuntan publik, kondisi ini terjadi karena keyakinan terhadap profesi adalah suatu keyakinan bahwa yang paling berwenang menilai pekerjaan profesional adalah rekan sesama profesi, bukan orang luar yang tidak mempunyai kompetensi dalam bidang ilmu dan pekerjaan auditor. Bila yang menilai pekerjaan mempunyai pengetahuan yang sama, maka kesalahan akan dapat diketahui.

e. Hubungan rekan seprofesi berpengaruh signifikan terhadap pertimbangan tingkat materialitas akuntan publik, kondisi ini terjadi karena hubungan dengan sesama profesi adalah menggunakan ikatan profesi sebagai acuan, termasuk didalamnya organisasi formal dan kelompok kolega informal sebagai ide utama dalam pekerjaan. Melalui ikatan profesi ini para profesionalisme membangun kesadaran profesional.

f. Etika profesi berpengaruh tidak signifikan terhadap tingkat materialitas akuntan publik, kondisi ini terjadi karena responden dalam penelitian ini adalah auditor junior, dimana pengetahuan tentang etika profesi banyak diperoleh di dunia pendidikan dan bukan berasal dari pengalaman, sehingga pandangan tentang etika profesi tidak beragam.

\section{Saran}

Berdasarkan hasil penelitian yang telah dilakukan, dapat diketahui bahwa pengabdian pada profesi, kemandirian, kyekinan pada profesi dan hubungan rekan seprofesi berpengaruh terhadap pertimbangan tingkat materialitas, untuk diberikan saran :

1. Profesionalisme dan pengetahuan mendeteksi kekeliruan dapat terus ditingkatkan dengan mengikuti pendidikan profesi akuntansi PPAk) agar tingkat meterialitas agar auditor lebih profesional.

2. Auditor lebih memahami etika profesi dan dengan memahami kode etik akuntansi agar diperoleh kualitas audit yang lebih baik, dengan mengikuti perkembangan standar-standar akuntansi yang terus berkembang dan baru.

\section{Keterbatasan}

Keterbatasan dalam penelitian ini adalah kuesioner yang didistribusikan secara langsung pada beberapa kantor akuntan publik di Kota Semarang, di mana rata-rata diisi oleh auditor-auditor junior. Cakupan penelitian untuk menganalisis jawaban responden auditor senior, dan manajer pada penelitian ini jumlahnya sedikit. Bahkan untuk responden yang memiliki jabatan partner peneliti tidak mendapatkan, sehingga hasil penelitian kurang dapat digeneralisasi.

\section{DAFTAR PUSTAKA}

Desiana. 2012. Pengaruh Profesionalisme, Pengetahuan Mendeteksi Kekeliruan, dan Etika Profesi Terhadap Pertimbangan Tingkat Materialitas: Studi Pada KAP di Surabaya. Berkala Ilmiah Mahasiswa Akuntansi, Vol.1 No. 1, Januari 2012. 
Faisal, et all. 2012 . pengaruh kompetensi, independensi dan profesionalisme terhadap kualitas audit dengan kecerdasan emosional sebagai variabel moderasi. Universitas Syiah Kuala Banda Aceh.

Hendro Wahyudi. 2006. Pengaruh Profesionalisme auditor terhadap tingkat materialitas dalam laporan keuangan. STIE Malangkuçeçwara. Malang.

Ghozali. 2006. Aplikasi Analisis Multivatiate dengan program SPSS, Badan Penerbit Universitas Diponegoro. Semarang.

Iriyadi dan Vannywati. 2011.Pengaruh Profesionalisme Auditor dan Etika Profesi AuditorTerhadap Pertimbangan Tingkat Materialitas. Jurnal Ilmiah Ranggagading, Vol. 11 No.2, Oktober 211:75-81.

Marfin \& Jaka. 2012. Analisis pengaruh profesionalisme terhadap tingkat material dalam proses pengauditan laporan keuangan (Studi Empiris pada Auditor Eksternal di Kota Semarang).

Sri Trianingsih. 2010 . profesionalisme auditor,kualitas audit dan tingkat dalam pemeriksaan laporan keuangan. Universitas Pembangunan Nasional “Veteran” Jawa Timur.

Sugiyono, 2007. Metode Penelitian Administrasi. Bandung: Alfabeta.

Sugiyono. 2011. Statistika Untuk Penelitian. Bandung: Alfabeta.

Syahrir. 2002. Analisis Hubungan Antara Profesionalisme Akuntan Publik Dengan Kinerja, Kepuasan kerja, Komitmen, dan Keinginan Berpindah. Tesis S2, Fakultas Ekonomi, Universitas Gajah Mada, Yogyakarta. 


\section{LAMPIRAN}

Tabel 1: Gambaran Umum Responden

Penyebaran Kuesioner

\begin{tabular}{llc}
\hline \multicolumn{1}{c}{ Keterangan } & Jumlah \\
\hline - & Kuesioner yang disebarkan & 50 kuesioner \\
- Kuesioner tidak kembali & 2 kuesioner \\
- Kuesioner kembali tetapi tidak dapat digunakan & 2 kuesioner \\
- Kuesioner yang digunakan & 46 kuesioner \\
- $\quad$ Respon rate & $92 \%$ \\
\hline
\end{tabular}

Tabel 2 : Uji Validitas

\begin{tabular}{lcccc}
\hline Variabel & No. Item & r hitung & r tabel & Keterangan \\
\hline \multirow{2}{*}{ Pengabdian pada } & 1. & 0,839 & 0,297 & Valid \\
profesi & 2. & 0,913 & 0,297 & Valid \\
& 3. & 0,929 & 0,297 & Valid \\
\hline \multirow{2}{*}{ Kewajiban sosial } & 1. & 0,924 & 0,297 & Valid \\
& 2. & 0,936 & 0,297 & Valid \\
\hline \multirow{3}{*}{ Kemandirian } & 3. & 0,948 & 0,297 & Valid \\
\hline \multirow{2}{*}{ Keyakinan pada } & 1. & 0,835 & 0,297 & Valid \\
profesi & 2. & 0,824 & 0,297 & Valid \\
& 3. & 0,847 & 0,297 & Valid \\
\hline \multirow{2}{*}{ Hubungan rekan } & 1. & 0,890 & 0,297 & Valid \\
seprofesi & 2. & 0,852 & 0,297 & Valid \\
& 3. & 0,851 & 0,297 & Valid \\
\hline \multirow{5}{*}{ Etika Profesi } & 1. & 0,835 & 0,297 & Valid \\
& 2. & 0,894 & 0,297 & Valid \\
& 3. & 0,899 & 0,297 & Valid \\
\hline & 1. & 0,838 & 0,297 & Valid \\
& 2. & 0,802 & 0,297 & Valid \\
& 3. & 0,794 & 0,297 & Valid \\
& 4. & 0,824 & 0,297 & Valid \\
& 5. & 0,795 & 0,297 & Valid \\
& 6. & 0,662 & 0,297 & Valid \\
& 7. & 0,759 & 0,297 & Valid \\
& 8. & 0,718 & 0,297 & Valid \\
& 10. & 0,677 & 0,297 & Valid \\
& 11. & 0,752 & 0,297 & Valid \\
& 12. & 0,766 & 0,297 & Valid \\
& 13. & 0,768 & 0,297 & Valid \\
\hline
\end{tabular}




\begin{tabular}{ccccc}
\hline & 1. & 0,725 & 0,297 & Valid \\
& 2. & 0,689 & 0,297 & Valid \\
& 3. & 0,790 & 0,297 & Valid \\
& 4. & 0,604 & 0,297 & Valid \\
Petimbangan & 5. & 0,489 & 0,297 & Valid \\
tingkat materialitas & 6. & 0,649 & 0,297 & Valid \\
& 7. & 0,578 & 0,297 & Valid \\
& 8. & 0,536 & 0,297 & Valid \\
& 9. & 0,714 & 0,297 & Valid \\
& 10. & 0,661 & 0,297 & Valid \\
& 11. & 0,571 & 0,297 & Valid \\
& 12. & 0,330 & 0,297 & Valid \\
\hline
\end{tabular}

Tabel 3 : Uji Realiabilitas

\begin{tabular}{lccc}
\hline \multicolumn{1}{c}{ Indikator } & Nilai Cronbact Alpha & Batas cronbact & \\
\hline Pengabdian pada profesi & 0,867 & Alpha & Keterangan \\
\hline Kewajiban sosial & 0,927 & 0,6 & Reliabel \\
\hline Kemandirian & 0,784 & 0,6 & Reliabel \\
\hline Keyakinan pada profesi & 0,827 & 0,6 & Reliabel \\
\hline Hubungan rekan seprofesi & 0,848 & 0,6 & Reliabel \\
\hline Etika Profesi & 0,941 & 0,6 & Reliabel \\
\hline $\begin{array}{l}\text { Pertimbangan tingkat mete- } \\
\text { rialitas }\end{array}$ & 0,829 & 0,6 & Realibel \\
\hline
\end{tabular}

Tabel 4 : Uji Normalitas

Normal P-P Plot of Regression Standardized Residual

Dependent Variable: Pertimbangan tingkat materialitas tinggi

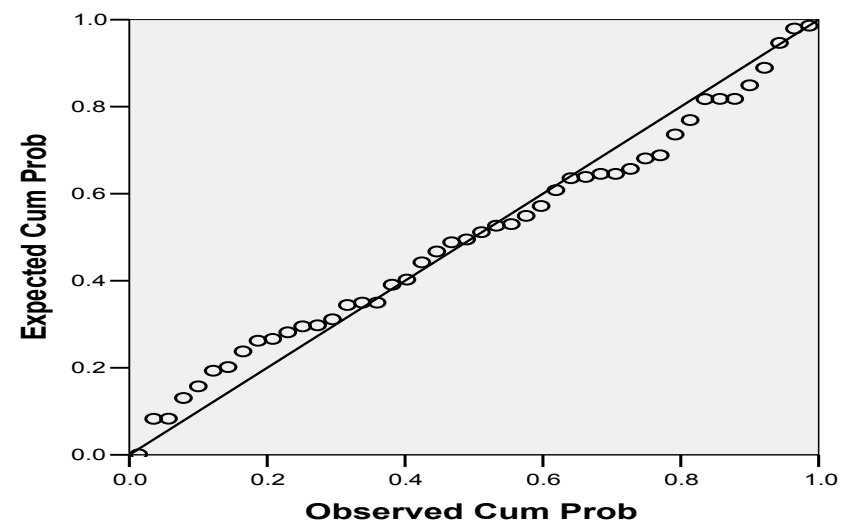


Tabel 5 : Uji Multikolinieritas

\begin{tabular}{|ll|r|r|}
\hline \multicolumn{3}{|c|}{ Coefficients $^{\mathbf{3}}$} \\
\hline \multirow{2}{*}{ Model } & \multicolumn{2}{c|}{ Collinearity Statistics } \\
\cline { 3 - 4 } & \multicolumn{1}{|c|}{ Tolerance } & VIF \\
\hline & Pengabdian pada profesi &, 392 & 2,553 \\
& kewajiban sosial &, 585 & 1,710 \\
& kemandirian &, 604 & 1,655 \\
& Keyakinan pada profesi &, 573 & 1,746 \\
& hubungan rekan &, 835 & 1,198 \\
& seprofesi &, 763 & 1,311 \\
\hline
\end{tabular}

a. Dependent Variable: Pertimbangan tingkat materialitas tinggi

\section{Tabel 6 : Uji Heteroskedast}

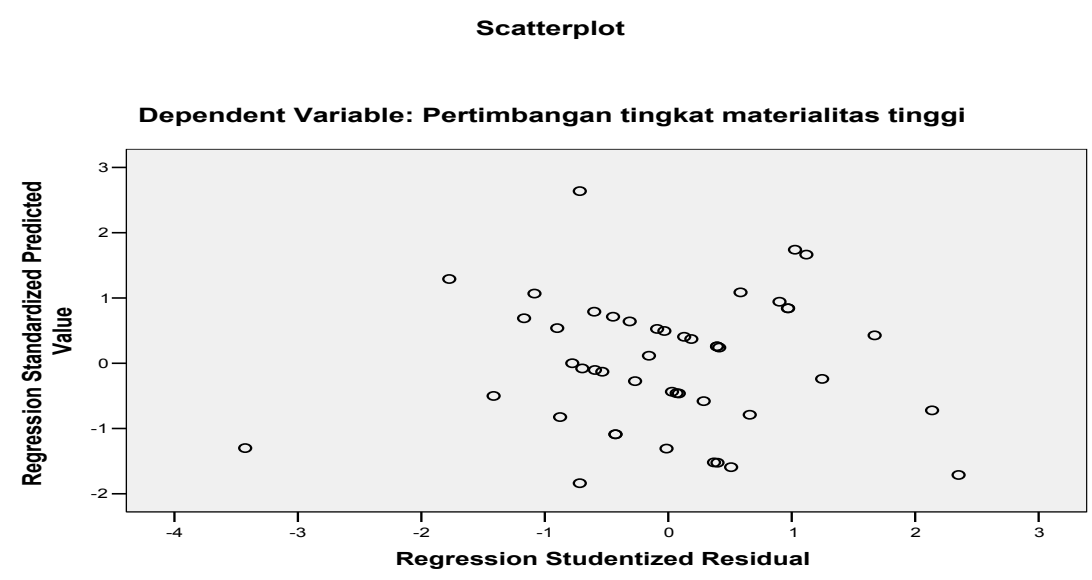

Tabel 7 : Uji F

ANOVA

\begin{tabular}{|c|c|c|c|c|c|c|}
\hline Model & & $\begin{array}{l}\text { Sum of } \\
\text { Squares }\end{array}$ & $\mathrm{df}$ & Mean Square & $F$ & Sig. \\
\hline \multirow[t]{3}{*}{1} & Regression & 895,573 & 6 & 149,262 & 21,750 &, $000^{a}$ \\
\hline & Residual & 267,645 & 39 & 6,863 & & \\
\hline & Total & 1163,217 & 45 & & & \\
\hline
\end{tabular}

a. Predictors: (Constant), etika profesi, kemandirian, hubungan rekan seprofesi, kewajiban sosial, Keyakinan pada profesi, Pengabdian pada profesi

b. Dependent Variable: Pertimbangan tingkat materialitas tinggi 
Tabel 8 : Uji t

Coefficients

\begin{tabular}{|c|c|c|c|c|c|c|}
\hline \multirow[b]{2}{*}{ Mode } & & \multicolumn{2}{|c|}{$\begin{array}{c}\text { Unstandardized } \\
\text { Coefficients }\end{array}$} & \multirow{2}{*}{$\begin{array}{c}\begin{array}{c}\text { Standardized } \\
\text { Coefficients }\end{array} \\
\text { Beta } \\
\end{array}$} & \multirow[b]{2}{*}{$\mathrm{t}$} & \multirow[b]{2}{*}{ Sig. } \\
\hline & & B & Std. Error & & & \\
\hline \multirow[t]{7}{*}{1} & (Constant) & 2,883 & 4,608 & & ,626 &, 535 \\
\hline & Pengabdian pada profesi & ,675 & ,270 & ,307 & 2,499 &, 017 \\
\hline & kewajiban sosial & ,341 & , 192 & 178 & 1,774 & 084 \\
\hline & kemandirian & ,754 & ,262 & ,284 & 2,875 & 007 \\
\hline & Keyakinan pada profesi & ,798 & ,267 & ,304 & 2,991 &, 005 \\
\hline & $\begin{array}{l}\text { hubungan rekan } \\
\text { seprofesi }\end{array}$ & 642 & , 196 & 276 & 3,280 & ,002 \\
\hline & etika profesi & , 104 & 059 & , 155 & 1,761 & 086 \\
\hline
\end{tabular}

a. Dependent Variable: Pertimbangan tingkat materialitas tinggi

\section{Kerangka Pemikiran Teoritis}

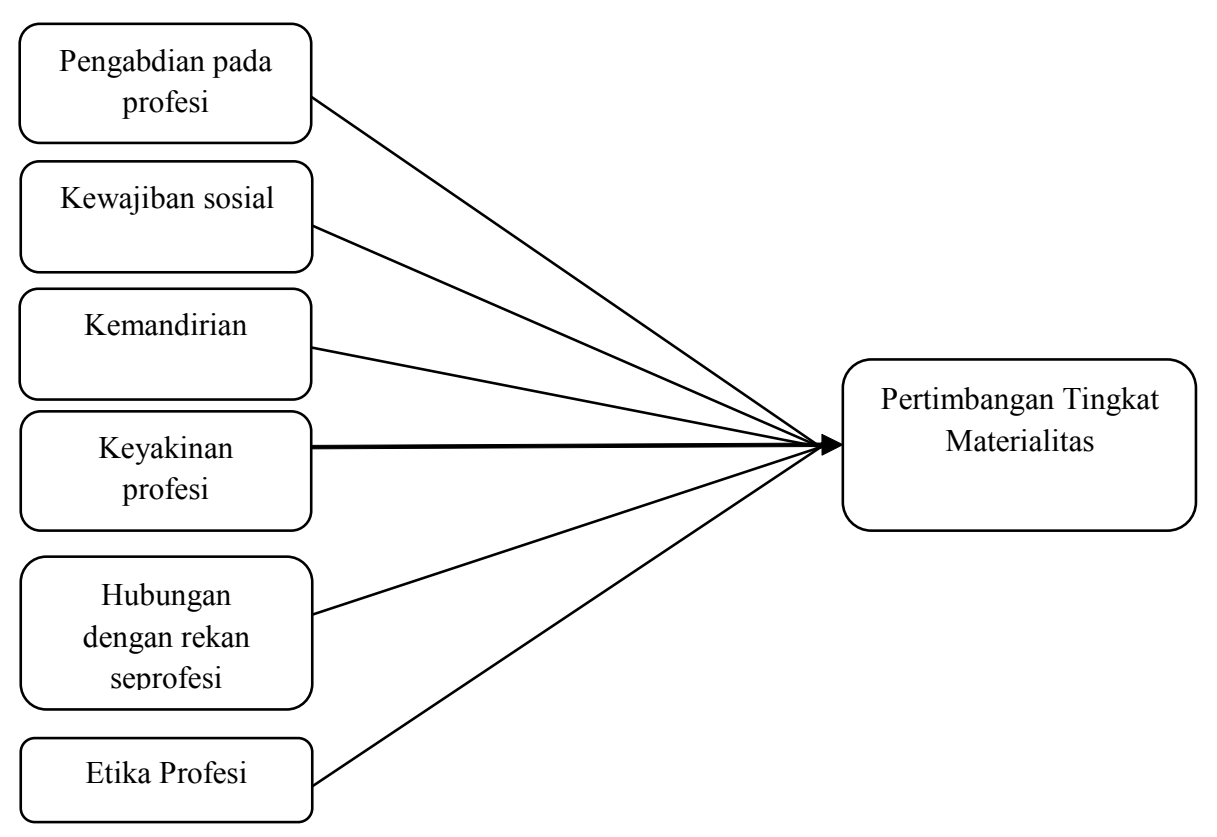


